\title{
Social Norms and Entrepreneurial Intent of Graduating University Students in North West Nigeria
}

\author{
Muhammad Kabir Abbas, Olutayo K. Osunsan, and Muhammad Kibuuka
}

\begin{abstract}
This study investigated the correlation between social norms and entrepreneurial intent of graduating university students in North West Nigeria. The study adopted quantitative research design. The study population was graduating students from seven universities selected from among the fourteen universities in Northwest Nigeria. A sample size of 379 was estimated from 24,000 graduating students using Krejcie and Morgan (1970) table. However, 364 questionnaires were retrieved. Simple random sampling was used to select the students who participated in the study. Data analysis was conducted using correlation analysis, and linear regression analysis of the study variables. The study revealed a positive and significant relationship between social norms and entrepreneurial intent $\left(r=.721^{* *} p=0.000<0.001\right)$. Furthermore, the study revealed that social norms can significantly explain $51.8 \%$ of the variation in entrepreneurial intent (Adjusted $R^{2}=0.518, \quad p=0.000<0.05$ ). The study concluded that appropriate social norms enhance development of entrepreneurial intent in students. The study recommended that the management of universities such as directorates of student welfare should put in place environments that promote building appropriate social norms among students.
\end{abstract}

Index Terms- Social Norms, Entrepreneurial Intent, Entrepreneurship, Northwest Nigeria.

\section{INTRODUCTION}

Entrepreneurship is a concept that has largely been accepted in the academic arena as an important element for promoting economic growth in Nigeria [1]. Indeed entrepreneurship is said to be the backbone of Nigeria's economy given the fact it accounts for more than eighty percent of enterprises that provide employment to about seventy percent of Nigeria's overall workforce [1]. However, recently entrepreneurial intent among young graduates has raised academic interest due to the ever increasing unemployment among students who have undergone entrepreneurship education and training. For instance, statistical data provides that the occurrence of graduate unemployment has reached a startling state. A 2018 report by National Bureau of Statistics indicated that graduate unemployment stood at 12.37 percent in 2015 , 23.67 percent in $2016,25.65$ percent in 2017 , and lately 29.75 percent in 2018. This statistical abstract therefore shades light that unemployment in the past four years has

Published on March 21, 2020.

Muhammad Kabir Abbas, Department of Business Administration, Hassan Usman Katsina Polytechnic, Katsina State, Nigeria.

(Corresponding email: kabirmabbas@gmail.com)

Olutayo K. Osunsan, Department of Business and Management, College of Economics and Management (CEM), Kampala International University, Uganda. (email: tayolist@gmail.com)

Muhammad Kibuuka, Department of Economics and Statistics, Kampala International University, Kampala Uganda.

(email: Muhammadkibuuka01@yahoo.com ) been on tremendous increase and shows no indication of slowing down any time soon among young graduates in Nigeria.

Although there is a high level of unemployment among young graduates, entrepreneurship education has not been a remedy to the problem of unemployment with graduates showing no intent of entrepreneurship [2]. However, research has demonstrated that entrepreneurship positively influences employment and welfare [3], yet little research has been done to explain how an individual's social norms influences their intention to become and succeed as entrepreneurs. Thus this study hypothesizes that social norms significantly affect entrepreneurial intent of graduating university students.

\section{LITERATURE REVIEW}

\section{A. Social Norm Theory}

The Social Norms Theory was advanced by Perkins and Berkowitz in 1986. The Social Norms Theory posits that individual behaviour is influenced by oftentimes perceptions of how other members of social groups or community think and act [4]. The Social Norms theory predicts that persons express or exhibit behaviour in an attempt to conform to a perceived norm [4]. Social norms relate to the perception of the societies about the particular behaviour. Norms govern much of the social and political life; an established norm can be very powerful. Prevailing social reward system plays a very important role to pave the way for the development of behaviour. The course of action that is more awarded and appreciated with in a particular society will be adopted by the members. With respect to entrepreneurship, some of the societies are levelled high in entrepreneurship in comparison to others. This may be that in these societies entrepreneurial activities are appreciated hence, people are more inclined towards entrepreneurship [5].

\section{B. Social Norm and Entrepreneur Intent}

A norm is a widely shared expectation about action. This expectation may be passive, as in expectations about customary or approved action, or active, as in enforced expectations [6]. Social norms refer to the perception of the societies about the particular behavior [7]. Conforming to social norms is often the appropriate course of action because collective wisdom tends to serve the individual, and the group, well. Among other things, it can provide a convenient decision-making heuristic and thus obviate the need to think critically about the consequences of each decision before acting on it [8]. Social norms are directly associated with entrepreneurship because they are the reason for differences among the societies with respect to entrepreneurial activities. 
Social norms are connected to how we think of what those who are close to us like family members and friends perceive of our entrepreneurial intent. Thus their perception greatly influences our entrepreneurial intent if we are not proactive in our decisions [9]. Although this may seem to be true to a greater extent that family and friends can affect an entrepreneur's business decision, other factors such as school environment have a greater part to play too. For instance, in a school environment where the administration, the curriculum, and teachers or lecturers are supportive of entrepreneurial ventures, it is highly likely that most students will have interest in venturing into entrepreneurship [10].

Social norms may affect the status attributed to different occupations. In this respect, social norms can help explain the origin of non-pecuniary benefits from entrepreneurial activity [11]. The prestige that different social norms attribute to occupations can affect occupational choice. More individuals may decide to become entrepreneurs in a community because they have characteristics that make them more prone to entrepreneurial activity [12]. Additionally, some communities could have certain characteristics, such as easier access to funds, which generate the correlation between individual and aggregate occupational choices [13].

A study investigated the extent to which differences in population, business environment and cultural values contributed to explaining differences in entrepreneurial activity across Swedish municipalities [14]. The results indicated that social norms contributed to entrepreneurial activity. The authors concluded that individuals were highly likely to become entrepreneurs where there were more entrepreneurs, even if entrepreneurial income was low.

Furthermore, a study explored the influence of entrepreneurial education on intention to embark on entrepreneurial project after graduation [15]. The results revealed that entrepreneurial education significantly influences one's intention to take on entrepreneurial activity. The study offers experiential evidence that would help educational institutions to formulate novel educational creativities that could support young graduates in shaping their entrepreneurial intention.

Another empirical study investigated the moderating outcome of perceived social norms on the association between entrepreneurial knowledge and graduates entrepreneurial intention [16]. The findings indicated a significant association between entrepreneurial knowledge and graduates entrepreneurial intention, however, the moderating outcome of perceived social norms on the association between entrepreneurial knowledge and graduates entrepreneurial intention was negatively supported, signifying that young graduates prefer white collar jobs to entrepreneurship due to negative societal attitude towards entrepreneurship.

Additionally, a study was conducted on the influence of some contextual elements on entrepreneurial intention of institution of higher education students [17]. The study found a positive relationship between entrepreneurship networks and entrepreneurial activities. The authors indicated that the networks were used for purposes such as idea development, access to financial and social support, and building inspirations towards entrepreneurial activities. Consequently, a related study found a positive correlation between the attitude of students towards entrepreneurship and social environment, with family, and social expectations of friends being moderating factors [18].

On the other hand, researchers have established that the absence of role models negatively affected entrepreneurial intentions among students [19]. The author argued that knowledge about a successful entrepreneur breeds entrepreneurial intent. This is because students who know of a successful entrepreneur would be more likely interested in entrepreneurship than those who have no such knowledge. The fact that entrepreneurship is controlled by the culture of an environment, students who live in entrepreneurially conducive environments will greatly be inclined to entrepreneurial venture.

In addition, a study was conducted to identify the factors that impact on entrepreneurial intention of tertiary students in Ghana [20]. The study found that financial support directly influences entrepreneurial intention. This is because knowledge of a financial support from family members and friends would motivate someone to venture into entrepreneurship.

However, other proponents did not find any significant association between social norms and entrepreneurial intention [21]. This is because social norms are considered very inadequate in explaining students' decisions to undertake entrepreneurial activities. In confirmation, a study on the factors affecting entrepreneurial intention of students of Vietnam National University found no significant relationship between social norms and entrepreneurial intention [22]. The authors argued that social norm may not be an essential element to a set of individuals who have strong traditions of entrepreneurship.

\section{Methodology}

The study adopted quantitative research design which focuses on numbers and collection of data to ensure the findings are generalizable to the population. The quantitative design, which is associated with interpretive philosophy, ensures that the study phenomena are understood in depth [23]. The choice for the design in this study allows generalization of the relationships between the study constructs, that is, social norms and entrepreneurial intent. The study population was graduating students from seven universities selected from among the fourteen universities in Northwest Nigeria. A sample size of 379 was estimated from 24,000 graduating students using Krejcie and Morgan (1970) table. However, 364 questionnaires were retrieved. Simple random sampling was used to select the students who would participate in the study. This sampling technique was preferred for its inclusiveness and nonbiasness.

This study used closed ended questionnaires to collect data from university graduating students. The importance of using closed questionnaires in a study ensures reaching of a large sample population, wide geographical coverage within a short time, and collection of only variables within interest [24]. The study employed a 5-likert scale, where 1=strongly disagree and 5=strongly agree. The study's preference of the Likert scale questionnaire was because it is the greatest worldwide technique for survey collection and the responses are easily quantifiable [25]. Statistical Package for Social 
Sciences (SPSS) version 22.0 was used to determine descriptive statistics, correlation analysis, and linear regression analysis of the study variables [26].

\section{RESULTS}

This section provides the descriptive statistics, inferential statistics of the correlation and linear regression between social norms and entrepreneurial intent among university graduating students in northwest Nigeria. Tables 1, 2, 3, and 4 give the summary of the findings.

TABLE 1: SOCIAL NORMS

\begin{tabular}{lll}
\hline \hline Social Norms & $\begin{array}{l}\text { Mean } \\
\overline{\mathbf{x}}\end{array}$ & $\begin{array}{l}\text { Std. } \\
\text { Deviation }\end{array}$ \\
\hline $\begin{array}{l}\text { Most of my friends show desire to start } \\
\text { enterprises }\end{array}$ & 0.65 & 0.747 \\
$\begin{array}{l}\text { Together with my friends we spend } \\
\text { much time talking about entering the }\end{array}$ & 4.46 & 0.762 \\
business arena & & \\
$\begin{array}{l}\text { My society gives more respect to } \\
\text { entrepreneurs }\end{array}$ & 4.35 & 0.931 \\
$\begin{array}{l}\text { My society encourages most people be } \\
\text { entrepreneurs }\end{array}$ & 4.23 & 0.948 \\
$\begin{array}{l}\text { Most of the people in my society people } \\
\text { prefer to start enterprises than be }\end{array}$ & 4.22 & 1.075 \\
employed & & .927 \\
$\begin{array}{l}\text { More often a person who is unable to } \\
\text { get job, starts his/ her business in our }\end{array}$ & 4.21 & \\
society. & & \\
$\begin{array}{l}\text { Business is seen as good work in my } \\
\text { society }\end{array}$ & 4.18 & 1.004 \\
$\begin{array}{l}\text { In my society business is regarded the } \\
\text { most dignified work }\end{array}$ & 4.10 & \\
Average & $\mathbf{4 . 3 0}$ & \\
\hline \hline
\end{tabular}

Source: Filed data, 2019

Table 1 shows that majority of the students strongly agreed that most of their friends show desire to start enterprises $(\bar{x}=4.65, \mathrm{Std}=0.747)$, and that together with their friends they spend much time talking about entering the business arena $(\bar{x}=4.46, \mathrm{Std}=0.762)$. In addition, majority of the students strongly agreed that their societies give more respect to entrepreneurs $(\overline{\mathrm{x}}=4.35, \mathrm{Std}=0.931)$, encourages most people to be entrepreneurs $(\bar{x}=4.23, \mathrm{Std}=0.948)$, thus such societies have made most people to prefer starting enterprises than be employed $(\overline{\mathrm{x}}=4.22, \quad \mathrm{Std}=1.075)$. Furthermore, majority of the students strongly agreed that in their societies, more often a person who is unable to get a job, starts his/ her business $(\bar{x}=4.21, \quad S t d=0.927)$. The students also agreed that businesses are seen as good work in their societies $(\bar{x}=4.18, S t d=1.004)$ and as such they are regarded as the most dignified work $(\overline{\mathrm{x}}=4.10, \mathrm{Std}=1.005)$.

The above responses imply that friends and societal attitude towards entrepreneurship is a driving force that shapes the entrepreneurial intent of graduating students in northwest Nigeria.
TABLE 2: ENTREPRENEURIAL INTENT

\begin{tabular}{lll}
\hline Entrepreneurial Intent & $\begin{array}{l}\text { Mean } \\
\overline{\mathbf{x}}\end{array}$ & Std. Deviation \\
\hline $\begin{array}{l}\text { Among various options, I would rather } \\
\text { be an entrepreneur }\end{array}$ & 4.29 & 0.679 \\
$\begin{array}{l}\text { I am up to the task of setting up my } \\
\text { business }\end{array}$ & 4.29 & 0.663 \\
$\begin{array}{l}\text { To set off a business and keep it } \\
\text { functioning would be easy for me }\end{array}$ & 4.20 & 0.992 \\
$\begin{array}{l}\text { I am capable to control the formation } \\
\text { process of a new business }\end{array}$ & 4.04 & 0.854 \\
$\begin{array}{l}\text { My qualification has offered me with } \\
\text { adequate knowledge required to start a }\end{array}$ & 4.01 & 0.684 \\
business & & \\
$\begin{array}{l}\text { It would be very easy for me to develop } \\
\text { a business idea }\end{array}$ & 3.98 & 0.876 \\
$\begin{array}{l}\text { I am prepared to do anything to be an } \\
\text { entrepreneur }\end{array}$ & 3.91 & 0.774 \\
$\begin{array}{l}\text { Being an entrepreneur implies more } \\
\text { merits than demerits to me }\end{array}$ & 3.90 & 1.084 \\
$\begin{array}{l}\text { I believe I am completely able to start a } \\
\text { business }\end{array}$ & 3.88 & 0.787 \\
\begin{tabular}{l} 
Average \\
\hline
\end{tabular} & & $\mathbf{4 . 0 6}$ \\
\hline
\end{tabular}

Interpretation: 4.21-5.00 (strongly agree); 3.41-4.20 (agree); 2.61-3.40 (not sure); 1.81-2.60 (disagree); and 1.00-1.80 (strongly disagree)

Table 2 shows that majority of the students strongly agreed that among various options, they would rather be entrepreneurs $(\bar{x}=4.29, S t d=0.679)$ by starting their own businesses $(\overline{\mathrm{x}}=4.29, \mathrm{Std}=0.663)$. In addition, several students agreed that it is easy for them to set up a business and keep it running $(\overline{\mathrm{x}}=4.20, \mathrm{Std}=0.992)$ since they already have the capability to control the formation process of any new business $(\bar{x}=4.04, \mathrm{Std}=0.854)$. Furthermore, students agreed that their qualifications have offered them with adequate knowledge required to start a business $(\overline{\mathrm{x}}=4.01, \mathrm{Std}=0.684)$, thus making it easier for them to develop business ideas $(\bar{x}=3.98, \mathrm{Std}=0.876)$. Similarly, most of the students agreed that they were well prepared to do anything to be entrepreneurs $(\overline{\mathrm{x}}=3.91, \mathrm{Std}=0.774)$. This is because they believed that being entrepreneurs implied more merits than demerits to them $(\bar{x}=3.90, S t d=1.084)$. Thus due to the merits attached to entrepreneurship, several students indicated that they would be able to start businesses $(\overline{\mathrm{x}}=3.88$, $\mathrm{Std}=0.787$ ).

The above responses imply that entrepreneurial education which is the same as environmental factors such as design of entrepreneurship curriculum, school policies that support entrepreneurship and availability of competent entrepreneurship teachers or lecturers triggers students' entrepreneurial intent.

TABLE 3: THE RELATIONSHIP BETWEEN SOCIAL NORMS AND ENTREPRENEURIAL INTENT

\begin{tabular}{lllc}
\hline \hline & & \multicolumn{2}{c}{$\begin{array}{c}\text { Entrepreneurial } \\
\text { Social Norms }\end{array}$} \\
& Pearson & 1 & $.721^{* *}$ \\
& Correlation & & .000 \\
& Sig. (2-tailed) & & 364 \\
\hline N & 364 &
\end{tabular}

**. Correlation is significant at the 0.01 level (2-tailed). 
Table 3 shows that there is a positive and significant relationship between social norms and entrepreneurial intent $\left(\mathrm{r}=.721^{* *} p=0.000<0.001\right)$. This implies that the higher the social norms that support entrepreneurship among graduating students, the higher the likelihood of having entrepreneurial intent.

TABLE 4: THE EFFECT OF SOCIAL NORMS ON ENTREPRENEURIAL INTENT

\begin{tabular}{|c|c|c|c|}
\hline Variables regressed & 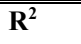 & $\overline{\mathbf{F}}$ & Sig \\
\hline $\begin{array}{lcc}\text { Social } & \text { norms } & \text { and } \\
\text { entrepreneurial intent } & \end{array}$ & 0.520 & 391.526 & 0.000 \\
\hline Coefficients & Beta & $\mathbf{t}$ & Sig \\
\hline Constant & 2.145 & 21.563 & 0.000 \\
\hline Social norms & 0.453 & 19.787 & 0.000 \\
\hline
\end{tabular}

a. Dependent Variable: Entrepreneurial Intent

Table 4 shows that social norms can significantly explain $52 \%$ of the variation in entrepreneurial intent (Adjusted $\left.\mathrm{R}^{2}=0.520, p=0.000<0.05\right)$. This implies that social norms significantly affect entrepreneurial intent. In other words, it signifies that friends and family members are mostly likely to influence the decision of graduating students to venture into entrepreneurship. That is to say, when friends and family are positive in terms of attitude and finance, then entrepreneurial intent can easily be hatched. Thus the earlier hypothesis that social norms significantly affect entrepreneurial intent of graduating university students is upheld and the null hypothesis is rejected. This is because the p-value $(0.000)$ is less than the universal acceptable value of 0.05 .

\section{DiscUSSION}

The study revealed that social norms had a direct and positive significant relationship with entrepreneurial intent. The direct relationship between social norms and entrepreneurial intent is also supported by previous scholars such as [17], [18], [20], and [22]. For example, one study found a positive correlation between the attitude of students towards entrepreneurship and social environment; with family, and social expectations of friends being moderating factors [18]. Likewise, another study found that financial support directly influenced entrepreneurial intention [20]. Additionally, a study found a positive relationship between entrepreneurship net-works and entrepreneurial activities [17]. These empirical findings therefore imply that social norms can help explain the origin of non-pecuniary benefits from entrepreneurial activity. The prestige that different social norms attribute to occupations can affect occupational choice. More individuals may decide to become entrepreneurs in a community because they have characteristics that make them more prone to entrepreneurial activity.

However, other studies found no significant relationship between social norms and entrepreneurial intent [19], [22]. The authors found that the absence of role models negatively affected entrepreneurial intentions among students, thus paving way for no influence of social norms on entrepreneurial intention.

\section{CONCLUSION}

This study investigated the effect of social norms on graduating students in northwest Nigeria. The finding indicated a positive relationship between the two variables. This implies that appropriate social norms enhance development of entrepreneurial intent in students. This is especially true when students are also accessing entrepreneurship education in institutions of higher learning such as universities. In other words, students who have undergone proper entrepreneurial education in their courses may easily feel the desire to venture into entrepreneurial activity if they have the support of their family members and friends in terms of finance. Thus, a positive entrepreneurial environment and supportive relatives are precursors of entrepreneurial intent among graduating students. Therefore, management of universities such as directorates of student welfare should put in place environments that promote building appropriate social norms among students. This should involve putting in place activities that make students get involved in discussing entrepreneurial activities and develop contacts with successful entrepreneurial environments.

\section{ACKNOWLEDGMENT}

We wish to express our sincere gratitude to God Almighty, for His loving kindness, guidance and protection that paved way for this great achievement of our educational quest. We also explicitly acknowledge the authors whose works were cited in this study. M. K. Abbas thanks his wife for her special cooperation during this academic voyage. O. K. Osunsan, and M. Kibuuka are thankful to the administration of College of Economics of Kampala International University for giving them a platform to explore academic heights. 


\section{REFERENCES}

[1] A. Adeoye, "The Effect of Entrepreneurship on Economy Growth and Development in Nigeria," International Journal of Development and Economic Sustainability, 3(2), pp. 49-65, 2015.

[2] S. E. Ogundipe, K. B. Adejoke, O. V. Olugbenga and Olatunde, "Entrepreneurial intention among business and counselling students in Lagos State University Sandwich Programme," Journal of Education and Practice, 3(14), pp. 64-72, 2012.

[3] S. A. Wennekers, A. Van Stel, M. Caree and R. Thurik, "). The relationship between entrepreneurship and economic development: Is it u-shaped?," Foundations and Trends in Entrepreneurship, pp. 6(3), 167-237, 2010.

[4] A. D. Berkowitz, "Applications of social norms theory to other health and social justice issues.," The social norms approach to preventing school and College age substance abuse: A handbook for educators, counselors and clinicians, pp. 259-279, 2003.

[5] H. Kothari, "Social norms and reward system affecting entrepreneurial intention," Journal of Commerce and Trade, 10(1) pp. 20-25, 2015.

[6] D. C. Bell and M. L. Cox, "Social norms: Do we love norms too much," Journal of Family Theory and Review, 7(1), pp. 28-46, 2015.

[7] A. Emami and D. Khajeheian, "Social Norms and Entrepreneurial Action: The Mediating Role of Opportunity Confidence," Sustainability, 11(1), p. 158, 2019.

[8] C. M. Lombardi, R. L. Coley, J. Sims, A. D. Lynch and J. Mahalik, "Social Norms, Social Connections, and Sex Differences in Adolescent Mental and Behavioral Health," Journal of Child and Family Studies, 28(1), pp. 91-104, 2019.

[9] I. Ajzen, "Nature and Operation of attitudes," Annul.Rev.Psychol, pp. 27-58, 2001.

[10] S. Saeeed, S. Y. Yousafzai, M. Yani-De-Soriano and M. Mu_atto, "The role of perceived university support in the formation of students' entrepreneurial intention," Journal of Small Business Management, pp. 1127-1145, 2015.

[11] N. F. Krueger, M. D. Reilly and A. L. Carrud, "Competing models of entrepreneurial intentions," Journal pf Business Venturing, 15(5), 2000 .

[12] I. Aj-Jubari, A. Hassan and F. Linan, "Entrepreneurial intention among University students in Malaysia: integrating selfdetermination theory and the theory of planned behavior," International Entrepreneurship and Management Journal, 15(4), pp. 1323-1342, 2019.

[13] B. M. Stout, "What will the Neighbours Think? Perceptions of Failure Intolerance on Individual Entrepreneurial Intention in the Rural Midwest," 2015. [Online]. Available: http://aquila.usm.edu/cgi/viewcontent.cgi?article=1197\&context=di ssertations. [Accessed 30 November 2019].

[14] M. Giannetti and A. Simonov, "On the determinants of entrepreneurial activity: Social norms, economic environment and individual characteristics.," Swedish Economic Policy Review, 11(2), pp. 269-313, 2004.

[15] G. Asimakopoulos, V. Hernandez and J. P. Miguel, "Entrepreneurial Intention of Engineering Students: The Role of Social Norms and Entrepreneurial Self-Efficacy," Sustainability, pp. 1-17, 2017.

[16] Y. Lamidi, D. Abdul, L. Poespowidjojo and A. Muhammedd, "Moderating effect of perceived social norms on the relationship between entrepreneurial knowledge and graduates entrepreneurial intention," Journal of Advanced Research in Business and Management Studies, pp. 21-31, 2019.

[17] P. Gelard and K. E. Saleh, "Impact of some contextual factors on entrrepreneurial intention of university students.," African Journal of Business Management, pp. 2-11, 2011.

[18] M. W. S. Fretschner, "Measuring and understanding the effects of entrepreneurial awareness education," Journal of Small Business Management, pp. 45-52, 2013.

[19] J. Lerner, "Entrepreneurship, Public Policy and Cities," Policy Research Working Paper, pp. 50-62, 2014.

[20] R. Denanyoh, K. Adjei and G. N. Nyenekye, "Factors that impact of entrepreneurial intention of tertiary students in Ghana," International Journal of Business and Social Research, pp. 1-11, 2015.

[21] A. Thomas, R. Passaro and G. Scandura, "The Perception of the Contextual Factors as Predictor of Entrepreneurial Intent: Evidence from an Empirical Survey," Journal of Entrepreneurship Culture, pp. $375-400,2014$

[22] M. N. Khuong and N. H. An, "The Factors Affecting Entrepreneurial Intention of the Students of Vietname National University-A mediation Analysis of Perception toward Entrepreneurship," Journal of Economics, Business and Management, pp. 22-34, 2016.

[23] M. Saunder, P. Lewis and A. Thornhill, Research Methods for Business Students, New York: Peason Education Limited, 2012.

[24] J. W. Creswell, Educational research: planning, conducting, and evaluating quantitative and qualitative research, NJ: Merrill: Upper Saddle River, 2012.

[25] M. Saunders, P. Lewis and A. Thornhill, Research methods for business students, New York: Pearson Education Limited, 2012.

[26] A. Field, Discovering statistics using SPSS, Los Angeles : SAGE Publications, 2009.

[27] N. F. Krueger and D. V. Brazeal, "Entrepreneurial Potential and Potential Entrepreneurs," Entrepreneurship Theory Practice, pp. 91$104,1994$. 